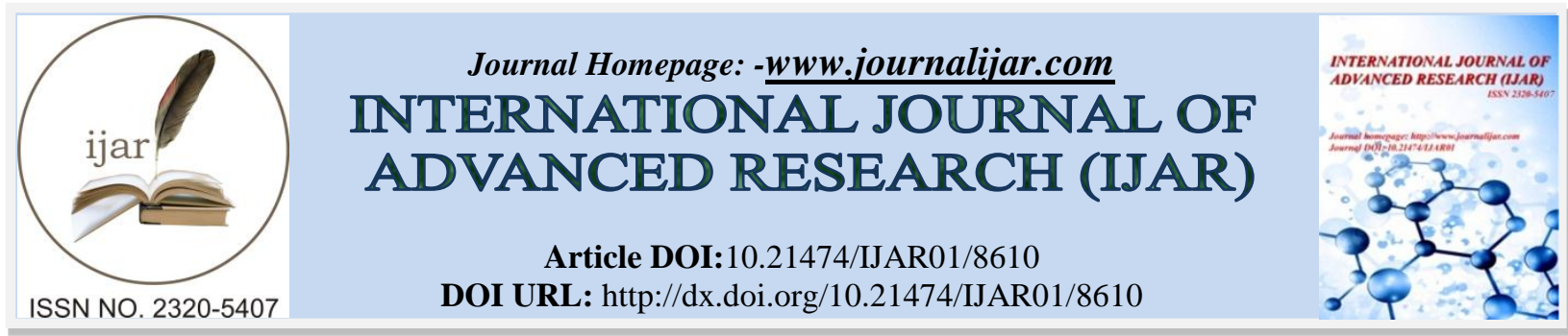

RESEARCH ARTICLE

\title{
RELATIONSHIP OF HEAVY METAL IN DIABETES AND NON-DIABETIC FOOT ULCER PATIENTS.
}

\section{Prasanta Kumar Bhattacharyya ${ }^{1}$, Priyanka Biswas ${ }^{2}$, Debarshi Jana ${ }^{3}$, Jayanta Ranjan Mukherjee ${ }^{1}$ and Madhusanta $\mathrm{De}^{2}$.}

1. KPC Medical College \& Hospital, Kolkata.

2. Ramakrishna Mission SevaPratishthan, Kolkata.

3. Institute of Post-Graduate Medical Education and Research, A.J.C. Bose Road, Kolkata-700020, West Bengal, India.

\section{Manuscript Info}

….......................

Manuscript History

Received: 04 January 2018

Final Accepted: 06 February 2019

Published: March 2019

Key words:-

Heavy metal, Arsenic, Diabetes, nondiabetic foot ulcer.

\section{Abstract}

Diabetic foot ulcer is a major complication of diabetes mellitus, and probably the major component of the diabetic foot. The aim of our study was to find out any relationship of heavy metals like Arsenic, Cadmium, Mercury, Lead, Chromium, Barium, Cobalt, Caesium We found that mean arsenic of Type2 DM with Foot Ulcer patients had significantly higher than others. Mean cadmium level had significantly lower in Type2 DM with Foot Ulcer than Healthy Control $(\mathrm{t}=3.5689)$. It may conclude that mercury level had lower in diabetic patients. Mean lead level had significantly higher in Type2 DM with Foot Ulcer than Healthy Control $(\mathrm{t}=2.3510)$. T-test showed that mean lead of Type2 DM with Foot Ulcer patients had significantly higher than others. Mean chromium level had significantly higher in Type2 DM with Foot Ulcer than others but that was not statistically significant. T-test showed that mean barium of Type2 DM without foot ulcer patients had significantly higher than others. Mean cobalt, caesium and selenium level had significantly higher in Type2 DM with Foot Ulcer than others but that was not statistically significant.

It can be suggested that toxic metals such as arsenic, cadmium, mercury, lead, chromium, barium, cobalt, caesium and selenium may have a role to induce foot ulcer in diabetic subjects.

Copy Right, IJAR, 2019,. All rights reserved.

\section{Introduction:-}

Diabetic foot ulcer is a major complication of diabetes mellitus, and probably the major component of the diabetic foot. Wound healing is an innate mechanism of action that works reliably most of the time. A key feature of wound healing is stepwise repair of lost extracellular matrix (ECM) that forms the largest component of the dermal skin layer. ${ }^{1}$ But in some cases, certain disorders or physiological insult disturbs the wound healing process. Diabetes mellitus is one such metabolic disorder that impedes the normal steps of the wound healing process. Many studies show a prolonged inflammatory phase in diabetic wounds, which causes a delay in the formation of mature granulation tissue and a parallel reduction in wound tensile strength. ${ }^{2}$ 
Treatment of diabetic foot ulcers should include: blood sugar control, removal of dead tissue from the wound, wound dressings, and removing pressure from the wound through techniques such as total contact casting. Surgery in some cases may improve outcomes. ${ }^{3}$ Hyperbaric oxygen therapy may also help but is expensive. ${ }^{3}$

It occurs in $15 \%$ of people with diabetes, ${ }^{4}$ and precedes $84 \%$ of all diabetes-related lower-leg amputations. ${ }^{5}$

Toxic heavy metals such as arsenic ( $\mathrm{As})$, lead $(\mathrm{Pb})$, and mercury $(\mathrm{Hg})$ are systemic toxicants that are hazardous to human health. However, as these elements are increasing in the environment due to fast urbanization, industrialization, and chemicalized agricultural activities, accumulation of the same in human body anywhere in the world is quite interesting to global assessment of environment quality. In this connection, random examination of blood samples of human population in Kerala, South India, was carried out to assess the threat of heavy metal contamination to humans in this part of the globe, especially in relation to the amount of such metals in food and other environmental samples. Except pure vegetarians, people of Kerala consume rice as the staple food with a lot of fish. Therefore, the amount of these three heavy metals in drinking water, fish, rice, and paddy soils was done. Heavy metals in the blood were examined in relation to age, gender, and dietary habits such as frequency of fish eating or vegetarianism. Influence of dental amalgam fillings on blood mercury levels was also analyzed. Quantitative assessment of metals in samples was done by inductively coupled plasma-mass spectrometry (ICPMS). The levels of arsenic, lead, and mercury were found well below the reference values, though diet seemed to pull them up as the amount of metals in blood showed significant differences between vegetarians and nonvegetarians. Evidence to the influence of dental amalgam fillings on blood mercury levels could not be established with the present samples.

To Study Role of Environmental Factors:-

1. Trace elements - Selenium.

2. Heavy metals - Arsenic, Cadmium, Mercurry, Lead, Chromium, Barium, Cobalt, Caesium.

\section{Materials And Methods:- \\ Inclusion Criteria \\ 1. Vascular foot ulcers \\ 2. Neuropathic foot ulcers \\ 3. Infective foot ulcers \\ 4. Healthy Control.}

\section{Exclusion Criteria}

1. Traumatic Ulcers

2. Steroid Induced Ulcers

3. Malignant Ulcers

4. Radiation Ulcers

5. Skin diseases

\section{Sample Design}

1. Healthy Control, 50

2. Diabetic population with foot ulcer, 50

3. Diabetic population without foot ulcer, 50

4. Non-diabetic population with foot ulcer, 50

\section{Study group:}

1. Healthy Control, 50 persons

2. Diabetic population with foot ulcer, 50patients

3. Diabetic population without foot ulcer, 50patients

4. Non-diabetic population with foot ulcer, 50patients 


\section{Statistical analysis:}

For statistical analysis data were entered into a Microsoft excel spreadsheet and then analyzed by SPSS (version 24.0; SPSS Inc., Chicago, IL, USA) and GraphPad Prism version 5. Data had been summarized as mean and standard deviation for numerical variables and count and percentages for categorical variables. Two-sample t-tests for a difference in mean involved independent samples or unpaired samples. Paired t-tests were a form of blocking and had greater power than unpaired tests. One-way analysis of variance (one-way ANOVA) was a technique used to compare means of three or more samples for numerical data (using the F distribution). A chi-squared test ( $\chi 2$ test) was any statistical hypothesis test wherein the sampling distribution of the test statistic is a chi-squared distribution when the null hypothesis is true. Without other qualification, 'chi-squared test' often is used as short for Pearson's chi-squared test. Unpaired proportions were compared by Chi-square test or Fischer's exact test, as appropriate.

p-value $\leq 0.05$ was considered for statistically significant.

\section{Results:-}

We found that in type2 DM with foot ulcer, the mean age (mean \pm s.d.) of patients was $4.6200 \pm 10.8438$ years. In non-diabetic foot ulcer, the mean age (mean \pm s.d.) of patients was $42.3600 \pm 13.4661$ years. In type2 DM without foot ulcer, the mean age (mean \pm s.d.) of patients was $50.5000 \pm 11.3986$ years. In Healthy Control, the mean age (mean \pm s.d.) of patients was $45.1800 \pm 15.2472$ years. Distribution of mean age vs. group was statistically significant $(\mathrm{p}<0.0001)$. It was found that association of sex vs. group was statistically significant $(\mathrm{p}<0.0001)$.

We found that in type2 DM with foot ulcer, the mean arsenic (mean \pm s.d.) of patients was $3.9860 \pm 1.3040 \mu \mathrm{g} / \mathrm{l}$. In non-diabetic foot ulcer, the mean arsenic (mean \pm s.d.) of patients was $2.5064 \pm .7588 \mu \mathrm{g} / \mathrm{l}$. In type2 DM without foot ulcer, the mean arsenic (mean \pm s.d.) of patients was $1.3776 \pm .1388 \mu \mathrm{g} / \mathrm{l}$. In Healthy Control, the mean arsenic (mean \pm s.d.) of patients was $1.3024 \pm .2364 \mu \mathrm{g} / \mathrm{l}$. Distribution of mean arsenic vs. group was statistically significant $(\mathrm{p}<0.0001)$.

It was found that in type2 DM with foot ulcer, the mean cadmium (mean \pm s.d.) of patients was $.5074 \pm .2551 \mu \mathrm{g} / \mathrm{l}$. In non diabetic foot ulcer, the mean cadmium (mean \pm s.d.) of patients was $.6814 \pm .2000 \mu \mathrm{g} / \mathrm{l}$. In type2 DM without foot ulcer, the mean cadmium (mean \pm s.d.) of patients was .8140 $\pm .3451 \mu \mathrm{g} / \mathrm{l}$. In Healthy Control, the mean cadmium (mean \pm s.d.) of patients was $.6728 \pm .2057 \mu \mathrm{g} / \mathrm{l}$. Distribution of mean cadmium vs. group was statistically significant $(\mathrm{p}<0.0001)$.

We found that in type2 DM with foot ulcer, the mean mercury (mean \pm s.d.) of patients was $1.1340 \pm .6895 \mu \mathrm{g} / \mathrm{l}$. In non diabetic foot ulcer, the mean mercury (mean \pm s.d.) of patients was $1.3304 \pm .5559 \mu \mathrm{g} / \mathrm{l}$. In type2 DM without foot ulcer, the mean mercury (mean \pm s.d.) of patients was $1.1232 \pm .4659 \mu \mathrm{g} / \mathrm{l}$. In Healthy Control, the mean mercury (mean \pm s.d.) of patients was $1.3974 \pm .5635 \mu \mathrm{g} / \mathrm{l}$. Distribution of mean mercury vs. group was statistically significant $(\mathrm{p}=0.0354)$.

We found that in type2 DM with foot ulcer, the mean lead (mean \pm s.d.) of patients was $36.8300 \pm 19.4565 \mu \mathrm{g} / \mathrm{l}$. In non-diabetic foot ulcer, the mean lead (mean \pm s.d.) of patients was $31.9012 \pm 17.2549 \mu \mathrm{g} / \mathrm{l}$. In type2 DM without foot ulcer, the mean lead (mean \pm s.d.) of patients was $30.0516 \pm 4.5093 \mu \mathrm{g} / \mathrm{l}$. In Healthy Control, the mean lead (mean \pm s.d.) of patients was $28.5864 \pm 15.3693 \mu \mathrm{g} / \mathrm{l}$. Distribution of mean lead vs. group was statistically significant $(\mathrm{p}=0.0432)$.

It was found that in type2 DM with foot ulcer, the mean chromium (mean \pm s.d.) of patients was $2.0360 \pm 7.5584$ $\mu \mathrm{g} / \mathrm{l}$. In non-diabetic foot ulcer, the mean chromium (mean \pm s.d.) of patients was $1.3420 \pm 2.4775 \mu \mathrm{g} / \mathrm{l}$. In type2 DM without foot ulcer, the mean chromium (mean \pm s.d.) of patients was $.6500 \pm .2244 \mu \mathrm{g} / \mathrm{l}$. In Healthy Control, the mean chromium (mean \pm s.d.) of patients was $.6150 \pm .2180 \mu \mathrm{g} / \mathrm{l}$. Distribution of mean chromium vs. group was not statistically significant $(\mathrm{p}=0.2391)$.

It was found that in type2 DM with foot ulcer, the mean barium (mean \pm s.d.) of patients was $26.0608 \pm 11.2050 \mu \mathrm{g} / \mathrm{l}$. In non diabetic foot ulcer, the mean barium (mean \pm s.d.) of patients was $11.6326 \pm 7.5489 \mu \mathrm{g} / \mathrm{l}$. In type $2 \mathrm{DM}$ without foot ulcer, the mean barium (mean \pm s.d.) of patients was $18.4122 \pm 9.4575 \mu \mathrm{g} / \mathrm{l}$. In Healthy Control, the mean barium (mean \pm s.d.) of patients was $11.5628 \pm 8.0150 \mu \mathrm{g} / \mathrm{l}$. Distribution of mean barium vs. group was statistically significant $(\mathrm{p}<0.0001)$. 
We found that in type $2 \mathrm{DM}$ with foot ulcer, the mean cobalt (mean \pm s.d.) of patients was $.8302 \pm 2.6928 \mu \mathrm{g} / \mathrm{l}$. In non diabetic foot ulcer, the mean cobalt (mean \pm s.d.) of patients was $.6194 \pm .4213 \mu \mathrm{g} / \mathrm{l}$. In type2 DM without foot ulcer, the mean cobalt (mean \pm s.d.) of patients was $.4240 \pm .1062 \mu \mathrm{g} / \mathrm{l}$. In Healthy Control, the mean cobalt (mean \pm s.d.) of patients was $.3580 \pm .1056 \mu \mathrm{g} / \mathrm{l}$. Distribution of mean cobalt vs. group was not statistically significant $(\mathrm{p}=0.3129)$.

It was found that in type $2 \mathrm{DM}$ with foot ulcer, the mean caesium (mean \pm s.d.) of patients was $2.1116 \pm .3510 \mu \mathrm{g} / \mathrm{l}$. In non diabetic foot ulcer, the mean caesium (mean \pm s.d.) of patients was $1.5332 \pm .3032 \mu \mathrm{g} / \mathrm{l}$. In type2 DM without foot ulcer, the mean caesium (mean \pm s.d.) of patients was $1.6418 \pm .9908 \mu \mathrm{g} / \mathrm{l}$. In Healthy Control, the mean caesium(mean \pm s.d.) of patients was $1.5224 \pm .3213 \mu \mathrm{g} / \mathrm{l}$. Distribution of mean caesium vs. group was statistically significant $(\mathrm{p}<0.0001)$.

We found that in type2 DM with foot ulcer, the mean selenium (mean \pm s.d.) of patients was $180.5586 \pm 28.8920$ $\mu \mathrm{g} / \mathrm{l}$. In non-diabetic foot ulcer, the mean selenium (mean \pm s.d.) of patients was $170.7362 \pm 26.7228 \mu \mathrm{g} / \mathrm{l}$. In type 2 $\mathrm{DM}$ without foot ulcer, the mean selenium (mean \pm s.d.) of patients was 150.6476 $\pm 37.0882 \mu \mathrm{g} / \mathrm{l}$. In Healthy Control, the mean selenium (mean \pm s.d.) of patients was $120.6164 \pm 22.9464 \mu \mathrm{g} / \mathrm{l}$. Distribution of mean selenium vs. group was statistically significant $(\mathrm{p}<0.0001)$.

We found that mean arsenic level had significantly higher in Type2 DM with Foot Ulcer than Healthy Control $(\mathrm{t}=14.3184)$. T-test showed that mean arsenic of Type2 DM with Foot Ulcer patients had significantly higher than others. Mean cadmium level had significantly lower in Type2 DM with Foot Ulcer than Healthy Control ( $\mathrm{t}=3.5689$ ). T-test showed that mean cadmium of Type2 DM with Foot Ulcer patients had significantly lower than others. Mean mercury level had significantly lower in Type2 DM with Foot Ulcer and Type2 DM without foot ulcer ( $\mathrm{t}=2.0917$ and 2.6518 respectively).It may conclude that mercury level had lower in diabetic patients. Mean lead level had significantly higher in Type2 DM with Foot Ulcer than Healthy Control $(\mathrm{t}=2.3510)$. T-test showed that mean lead of Type2 DM with Foot Ulcer patients had significantly higher than others.

Mean chromium level had significantly higher in Type2 DM with Foot Ulcer than others but that was not statistically significant. Mean barium level had significantly higher in Type2 DM without foot ulcer than Healthy Control $(\mathrm{t}=7.4414)$. T-test showed that mean barium of Type2 DM without foot ulcer patients had significantly higher than others. Mean cobalt level had significantly higher in Type2 DM with Foot Ulcer than others but that was not statistically significant. Mean caesium level had significantly higher in Type 2 DM with Foot Ulcer than Healthy Control $(\mathrm{t}=8.7551)$. T-test showed that mean caesium of Type2 DM with Foot Ulcer patients had significantly higher than others. Mean selenium level had significantly higher in Type2 DM with Foot Ulcer than Healthy Control $(\mathrm{t}=11.4880)$. T-test showed that mean selenium of Type2 DM with Foot Ulcer patients had significantly higher than others.

\section{Discussion:-}

Diabetic foot ulcer is the common dreadful complication of diabetes mellitus. The lifetime prevalence of foot ulceration is about 15\%. ${ }^{6}$ Macro and microvascular involvement and neuropathy plays a major role in the pathophysiology of diabetic foot ulcers. ${ }^{7}$ According to the Diabetes Atlas 2013 published by the International Diabetes Federation, the number of people with diabetes in India currently is 65.1 million, which is expected to rise to 142.7 million by $2035 .^{8}$ Mean age of the study population was 51 years, which is in par with the previous studies in India. ${ }^{9}$

We found that mean age was higher in type $2 \mathrm{DM}$ with foot ulcer patients than others and that was statistically significant $(\mathrm{p}<0.0001)$.Present study found that male had more prevalence in Type2 DM with Foot Ulcer and it was statistically significant $(\mathrm{p}<0.0001)$. In type $2 \mathrm{DM}$ with foot ulcer, higher number of patients $16(32.0 \%)$ were house wives. In non-diabetic foot ulcer, higher number of patients $28(56.0 \%)$ were house wives. In type $2 \mathrm{DM}$ without foot ulcer, higher number of patients $26(52.0 \%)$ were house wives. In healthy control, higher number of patients $29(58.0 \%)$ were house wives. Association of occupation vs. group was not statistically significant $(\mathrm{p}=0.0002)$.

Some metals (e.g. magnesium) are known as macro-metals and are found in high amount in the body tissues, therefore they are also called macro-nutrients. ${ }^{10}$ At least $100 \mathrm{mg}$ of each macro-nutrient is required in the daily diet ${ }^{11}$. In contrast, some metals e.g. copper $(\mathrm{Cu})$, zinc $(\mathrm{Zn})$, iron $(\mathrm{Fe})$ and manganese $(\mathrm{Mn})$, chromium $(\mathrm{Cr})$ etc. are needed in the body in very small amounts, less than 100 parts per million (ppm), hence, these are called trace elements or micro-nutrients ${ }^{12}$. Metals are involved in a range of physiological processes such as prosthetic groups of many proteins, water balance, cofactors of many enzymes etc. ${ }^{13}$ Several metals function as part of 
proteins/enzymes as metalloproteinase/metalloenzymes. ${ }^{14}$ Such proteins without metal containing prosthetic groups are unable to perform their physiological functions. ${ }^{15}$ The regulation of various metallic contents in the body is prerequisite for their proper functioning. ${ }^{16}$ Metals enable the muscles to contract or relax, and also transmit impulses through the nerves. Most metals are available in the soluble salt forms, which regulate the composition of biofluids. The proper metabolic functioning of the trace elements depends on their normal levels in various body tissues. ${ }^{17}$ Due to the diversified metabolic characteristics and functions; various metals such as $\mathrm{Mg}, \mathrm{Zn}, \mathrm{Cr}, \mathrm{Fe}, \mathrm{Mn}$ and $\mathrm{Cu}$ are considered as essential for normal human health. Several studies have reported that the imbalance of some essential metals might adversely affect pancreatic islet and cause development of diabetes. ${ }^{18} \mathrm{It}$ is also manifested that some reactive oxygen species (ROS) are produced during diabetes due to imbalance of essential metals. This oxidative stress might decrease the insulin gene promoter activity and mRNA expression in pancreatic islet cells due to hyperglycemic condition. ${ }^{19-20}$

We found that mean arsenic level had significantly higher in Type2 DM with Foot Ulcer than Healthy Control $(\mathrm{t}=14.3184)$. T-test showed that mean arsenic of Type2 DM with Foot Ulcer patients had significantly higher than others.

It was found that mean cadmium level was significantly lower in Type2 DM with Foot Ulcer than Healthy Control $(\mathrm{t}=3.5689)$. T-test showed that mean cadmium of Type2 DM with Foot Ulcer patients was significantly lower than others. Mean mercury level was significantly lower in Type2 DM with Foot Ulcer and Type2 DM without foot ulcer $(\mathrm{t}=2.0917$ and 2.6518 respectively).It may conclude that mercury level was lower in diabetic patients. Mean lead level wassignificantly higher in Type2 DM with Foot Ulcer than Healthy Control $(t=2.3510)$. T-test showed that mean lead of Type2 DM with Foot Ulcer patients were significantly higher than others.Mean chromium level was significantly higher in Type2 DM with Foot Ulcer than others but that was not statistically significant.

We found that mean barium level was significantly higher in Type2 DM without foot ulcer than Healthy Control $(\mathrm{t}=7.4414)$. T-test showed that mean barium of Type2 DM without foot ulcer patients was significantly higher than others.Mean cobalt level was significantly higher in Type2 DM with Foot Ulcer than others but that was not statistically significant. Mean caesiumlevel was significantly higher in Type2 DM with Foot Ulcer than Healthy Control $(\mathrm{t}=8.7551)$. T-test showed that mean caesium of Type2 DM with Foot Ulcer patients were significantly higher than others.Mean selenium level was significantly higher in Type2 DM with Foot Ulcer than Healthy Control $(\mathrm{t}=11.4880)$. T-test showed that mean selenium of Type2 DM with Foot Ulcer patients was significantly higher than others.

\section{Conclusion:-}

From our study on derangement of metals in diabetes, it could be concluded that normal levels of essential metals are disturbed in T2D patients. It can be suggested that toxic metals such as arsenic, cadmium, mercury, lead, chromium, barium, cobalt, caesium and selenium may have a role to induce foot ulcer in diabetic subjects.

1. Heavy metal toxicity may have significance in the occurrence of DFU.

2. Future work can be done to find the causative effect of heavy metals in DFU.

3. Pollution from soil, water, food, air may have some action.

4. Regional variation between cities and villages and varied geographical samples may direct to the aetiopathogenesis of this dreaded DFU.

Table1:- Distribution of mean heavy metals in four groups

\begin{tabular}{|c|c|c|c|c|c|c|c|c|}
\hline \multirow{3}{*}{$\begin{array}{c}\text { ARSENIC } \\
\boldsymbol{\mu g} / \mathbf{l}\end{array}$} & $\begin{array}{c}\text { Gype2 DM with } \\
\text { foot ulcer }\end{array}$ & 50 & 3.9860 & 1.3040 & 2.1000 & 5.8900 & 4.2500 & $<0.0001$ \\
\cline { 2 - 7 } & $\begin{array}{c}\text { Non diabetic foot } \\
\text { ulcer }\end{array}$ & 50 & 2.5064 & .7588 & 1.2500 & 5.2300 & 2.6700 & \\
\cline { 2 - 7 } & $\begin{array}{c}\text { Type2 DM } \\
\text { without foot ulcer }\end{array}$ & 50 & 1.3776 & .1388 & 1.2200 & 1.6400 & 1.3150 & \\
\cline { 2 - 7 } & Healthy Control & 50 & 1.3024 & .2364 & 1.0100 & 1.7100 & 1.2350 & \\
\hline \multirow{2}{*}{$\begin{array}{c}\mathbf{C A D M I U M} \\
\boldsymbol{\mu g} / \mathbf{l}\end{array}$} & $\begin{array}{c}\text { Type2 DM with } \\
\text { foot ulcer }\end{array}$ & 50 & .5074 & .2551 & 0.2000 & 0.9700 & 0.4550 & $<0.0001$ \\
\cline { 2 - 7 } & Non diabetic foot & 50 & .6814 & .2000 & 0.4000 & 0.9400 & 0.7800 & \\
\hline
\end{tabular}




\begin{tabular}{|c|c|c|c|c|c|c|c|c|}
\hline & ulcer & & & & & & & \\
\hline & $\begin{array}{c}\text { Type2 DM } \\
\text { without foot ulcer }\end{array}$ & 50 & .8140 & .3451 & 0.2000 & 1.6200 & 0.9300 & \\
\hline & Healthy Control & 50 & .6728 & .2057 & 0.4500 & 0.9400 & 0.7800 & \\
\hline \multirow[t]{4}{*}{$\begin{array}{c}\text { MERCURY } \\
\mu \mathrm{g} / \mathrm{l}\end{array}$} & $\begin{array}{l}\text { Type2 DM with } \\
\text { foot ulcer }\end{array}$ & 50 & 1.1340 & .6895 & 0.4500 & 2.6400 & 0.9000 & \multirow[t]{4}{*}{0.0354} \\
\hline & $\begin{array}{l}\text { Non diabetic foot } \\
\text { ulcer }\end{array}$ & 50 & 1.3304 & .5559 & 0.5000 & 1.8900 & 1.4500 & \\
\hline & $\begin{array}{c}\text { Type2 DM } \\
\text { without foot ulcer }\end{array}$ & 50 & 1.1232 & .4659 & 0.4500 & 2.6400 & 1.1900 & \\
\hline & Healthy Control & 50 & 1.3974 & .5635 & 0.5000 & 1.8900 & 1.4500 & \\
\hline
\end{tabular}

\begin{tabular}{|c|c|c|c|c|c|c|c|c|}
\hline & Group & Number & Mean & SD & Minimum & Maximum & Median & p-value \\
\hline \multirow[t]{4}{*}{ LEAD $\mu \mathrm{g} / \mathrm{l}$} & $\begin{array}{l}\text { Type2 DM } \\
\text { with foot } \\
\text { ulcer }\end{array}$ & 50 & 36.8300 & 19.4565 & 1.4800 & 54.3800 & 51.8300 & \multirow[t]{4}{*}{0.0432} \\
\hline & $\begin{array}{l}\text { Non diabetic } \\
\text { foot ulcer }\end{array}$ & 50 & 31.9012 & 17.2549 & 13.3900 & 58.0600 & 30.2300 & \\
\hline & $\begin{array}{c}\text { Type2 DM } \\
\text { without foot } \\
\text { ulcer }\end{array}$ & 50 & 30.0516 & 4.5093 & 13.7200 & 42.5700 & 30.2500 & \\
\hline & $\begin{array}{l}\text { Healthy } \\
\text { Control }\end{array}$ & 50 & 28.5864 & 15.3693 & 13.3900 & 53.3300 & 24.1800 & \\
\hline \multirow[t]{4}{*}{$\underset{\mu \mathrm{g} / \mathrm{l}}{\text { CHROMIUM }}$} & $\begin{array}{c}\text { Type2 DM } \\
\text { with foot } \\
\text { ulcer }\end{array}$ & 50 & 2.0360 & 7.5584 & 0.7400 & 54.3800 & 0.9500 & \multirow[t]{4}{*}{0.2391} \\
\hline & $\begin{array}{l}\text { Non diabetic } \\
\text { foot ulcer }\end{array}$ & 50 & 1.3420 & 2.4775 & 0.5700 & 11.0200 & 0.6200 & \\
\hline & $\begin{array}{c}\text { Type2 DM } \\
\text { without foot } \\
\text { ulcer }\end{array}$ & 50 & .6500 & .2244 & 0.3600 & 1.0000 & 0.5350 & \\
\hline & $\begin{array}{l}\text { Healthy } \\
\text { Control }\end{array}$ & 50 & .6150 & .2180 & 0.5200 & 2.1000 & 0.5900 & \\
\hline \multirow[t]{4}{*}{ BARIUM $\mu \mathrm{g} / \mathrm{l}$} & $\begin{array}{c}\text { Type2 DM } \\
\text { with foot } \\
\text { ulcer }\end{array}$ & 50 & 26.0608 & 11.2050 & 0.7400 & 38.2600 & 32.3600 & \multirow[t]{4}{*}{$<0.0001$} \\
\hline & $\begin{array}{l}\text { Non diabetic } \\
\text { foot ulcer }\end{array}$ & 50 & 11.6326 & 7.5489 & 2.2500 & 23.4600 & 12.3300 & \\
\hline & $\begin{array}{c}\text { Type2 DM } \\
\text { without foot } \\
\text { ulcer }\end{array}$ & 50 & 18.4122 & 9.4575 & 2.3800 & 28.8200 & 19.5900 & \\
\hline & $\begin{array}{l}\text { Healthy } \\
\text { Control }\end{array}$ & 50 & 11.5628 & 8.0150 & 2.2500 & 23.4600 & 10.3700 & \\
\hline \multirow[t]{4}{*}{ COBALT $\mu \mathrm{g} / \mathrm{l}$} & $\begin{array}{l}\text { Type2 DM } \\
\text { with foot } \\
\text { ulcer }\end{array}$ & 50 & .8302 & 2.6928 & 0.3600 & 19.4800 & 0.3700 & \multirow[t]{4}{*}{0.3129} \\
\hline & $\begin{array}{l}\text { Non diabetic } \\
\text { foot ulcer }\end{array}$ & 50 & .6194 & .4213 & 0.2300 & 1.2300 & 0.3800 & \\
\hline & $\begin{array}{c}\text { Type2 DM } \\
\text { without foot } \\
\text { ulcer }\end{array}$ & 50 & .4240 & .1062 & 0.2400 & 0.5300 & 0.4500 & \\
\hline & $\begin{array}{l}\text { Healthy } \\
\text { Control }\end{array}$ & 50 & .3580 & .1056 & 0.2300 & 0.5100 & 0.3450 & \\
\hline
\end{tabular}

\begin{tabular}{l|c|c|c|c|c|c|c|} 
Group & Number & Mean & SD & Minimum & Maximum & Median & p-value \\
\hline
\end{tabular}




\begin{tabular}{|c|c|c|c|c|c|c|c|c|}
\hline \multirow[t]{4}{*}{$\begin{array}{c}\text { CAESIUM } \\
\mu \mathrm{g} / \mathrm{l}\end{array}$} & $\begin{array}{c}\text { Type2 DM } \\
\text { with foot } \\
\text { ulcer }\end{array}$ & 50 & 2.1116 & .3510 & 0.5700 & 2.4100 & 2.2500 & \multirow[t]{4}{*}{$<0.0001$} \\
\hline & $\begin{array}{l}\text { Non diabetic } \\
\text { foot ulcer }\end{array}$ & 50 & 1.5332 & .3032 & 1.1700 & 2.0400 & 1.5300 & \\
\hline & $\begin{array}{c}\text { Type2 DM } \\
\text { without foot } \\
\text { ulcer }\end{array}$ & 50 & 1.6418 & .9908 & 0.9700 & 3.2100 & 1.0400 & \\
\hline & $\begin{array}{l}\text { Healthy } \\
\text { Control }\end{array}$ & 50 & 1.5224 & .3213 & 1.1700 & 2.0400 & 1.3900 & \\
\hline \multirow[t]{4}{*}{$\begin{array}{c}\text { SELENIUM } \\
\mu \mathrm{g} / \mathrm{l}\end{array}$} & $\begin{array}{c}\text { Type2 DM } \\
\text { with foot } \\
\text { ulcer }\end{array}$ & 50 & 180.5586 & 28.8920 & 117.0500 & 200.9600 & 190.6200 & \multirow[t]{4}{*}{$<0.0001$} \\
\hline & $\begin{array}{l}\text { Non diabetic } \\
\text { foot ulcer }\end{array}$ & 50 & 170.7362 & 26.7228 & 110.2200 & 200.8800 & 160.5600 & \\
\hline & $\begin{array}{c}\text { Type2 DM } \\
\text { without foot } \\
\text { ulcer }\end{array}$ & 50 & 150.6476 & 37.0882 & 97.0900 & 200.3600 & 129.7400 & \\
\hline & $\begin{array}{l}\text { Healthy } \\
\text { Control }\end{array}$ & 50 & 120.6164 & 22.9464 & 84.2900 & 200.4500 & 117.0500 & \\
\hline
\end{tabular}

Table 2:- Distribution of heavy metals in four groups

\begin{tabular}{|c|c|c|c|}
\hline & & T Statistic & P-value \\
\hline \multirow[t]{3}{*}{ ARSENIC $\mu \mathrm{g} / \mathrm{l}$} & Type2 DM with Foot Ulcer vs Healthy Control & 14.3184 & $<0.0001$ \\
\hline & Type2 DM without Foot Ulcer vs Healthy Control & 1.9399 & 0.0553 \\
\hline & Non diabetic foot ulcer vs Healthy Control & 10.7116 & $<0.0001$ \\
\hline \multirow[t]{3}{*}{ CADMIUM $\mu \mathrm{g} / \mathrm{I}$} & Type2 DM with Foot Ulcer vs Healthy Control & 3.5689 & $<0.0001$ \\
\hline & Type2 DM without Foot Ulcer vs Healthy Control & 2.4852 & 0.0146 \\
\hline & Non diabetic foot ulcer vs Healthy Control & 0.2120 & 0.8326 \\
\hline \multirow[t]{3}{*}{ MERCURY $\mu \mathrm{g} / \mathrm{l}$} & Type2 DM with Foot Ulcer vs Healthy Control & 2.0917 & 0.0391 \\
\hline & Type2 DM without Foot Ulcer vs Healthy Control & 2.6518 & 0.0093 \\
\hline & Non diabetic foot ulcer vs Healthy Control & 0.5985 & 0.5509 \\
\hline \multirow[t]{3}{*}{ LEAD $\mu \mathrm{g} / \mathrm{l}$} & Type2 DM with Foot Ulcer vs Healthy Control & 2.3510 & 0.0207 \\
\hline & Type2 DM without Foot Ulcer vs Healthy Control & 0.6468 & 0.5192 \\
\hline & Non diabetic foot ulcer vs Healthy Control & 1.0144 & 0.3129 \\
\hline \multirow{3}{*}{$\underset{\mu \mathrm{g} / \mathrm{l}}{\mathrm{CHROMIUM}}$} & Type2 DM with Foot Ulcer vs Healthy Control & 1.3288 & 0.1870 \\
\hline & Type2 DM without Foot Ulcer vs Healthy Control & 0.7911 & 0.4308 \\
\hline & Non diabetic foot ulcer vs Healthy Control & 2.0670 & 0.0414 \\
\hline \multirow[t]{3}{*}{ BARIUM $\mu \mathrm{g} / \mathrm{l}$} & Type2 DM with Foot Ulcer vs Healthy Control & 7.4414 & $<0.0001$ \\
\hline & Type2 DM without Foot Ulcer vs Healthy Control & 3.9068 & 0.0002 \\
\hline & Non diabetic foot ulcer vs Healthy Control & 0.0448 & 0.9643 \\
\hline \multirow[t]{3}{*}{ COBALT $\mu \mathrm{g} / \mathrm{l}$} & Type2 DM with Foot Ulcer vs Healthy Control & 1.2390 & 0.2183 \\
\hline & Type2 DM without Foot Ulcer vs Healthy Control & 3.1151 & 0.0024 \\
\hline & Non diabetic foot ulcer vs Healthy Control & 4.2554 & $<0.0001$ \\
\hline \multirow[t]{3}{*}{ CAESIUM $\mu \mathrm{g} / \mathrm{l}$} & Type2 DM with Foot Ulcer vs Healthy Control & 8.7551 & $<0.0001$ \\
\hline & Type2 DM without Foot Ulcer vs Healthy Control & 0.8106 & 0.4196 \\
\hline & Non diabetic foot ulcer vs Healthy Control & 0.1729 & 0.8631 \\
\hline \multirow[t]{3}{*}{ SELENIUM $\mu \mathrm{g} / \mathrm{l}$} & Type2 DM with Foot Ulcer vs Healthy Control & 11.4880 & $<0.0001$ \\
\hline & Type2 DM without Foot Ulcer vs Healthy Control & 4.8690 & $<0.0001$ \\
\hline & Non diabetic foot ulcer vs Healthy Control & 10.0617 & $<0.0001$ \\
\hline
\end{tabular}




\section{Reference:-}

1. Nomikos IN, Malizos C, Vamvakopoulos NC. Protective and damaging aspects of healing: a review. WOUNDS-A COMPENDIUM OF CLINICAL RESEARCH AND PRACTICE. 2006 Jul 1;18(7):177-85.

2. Balaji, S.; Han, N.; Moles, C.; Shaaban, A.F.; Bollyky, P.L.; Crombleholme, T.M.; Keswani, S.G. Angiopoietin-1 improves endothelial progenitor cell-dependent neovascularization in diabetic wounds. Surgery 2015, 158,846-856.

3. Yazdanpanah L, Nasiri M, Adarvishi S. Literature review on the management of diabetic foot ulcer. World journal of diabetes. 2015 Feb 15;6(1):37.

4. Brem H, Tomic-Canic M. Cellular and molecular basis of wound healing in diabetes. The Journal of clinical investigation. 2007 May 1;117(5):1219-22.

5. Turns M. Diabetic foot ulcer management: the podiatrist's perspective. British journal of community nursing. 2013 Dec 1;18(Sup12):S14-9.

6. Reiber GE, Boyko EJ, Smith DG. Lower extremity foot ulcers and amputations in diabetes.Diabetes in America. 1995 Jul 1;2:40927.

7. Stockl K, Vanderplas A, Tafesse E, Chang E. Costs of lower-extremity ulcers among patients with diabetes. Diabetes Care. 2004 Sep 1;27(9):2129-34.

8. Whiting DR, Guariguata L, Weil C, Shaw J. IDF diabetes atlas: 6.global estimates of the prevalence of diabetes for 2011 and 2030. Diabetes Res Clin Pr. 2013;94(3):311-21

9. Viswanathan V, Thomas N, Tandon N, Asirvatham A, Rajasekar S. Profile of diabetic foot complications and its associated complications-a multicentric study from India. JAPI. 2005 Nov 7;53:933-6.

10. Ghisleni MM, Biolchi V, Jordon BC, et al. Association study of C936T polymorphism of the VEGF gene and the C242T polymorphism of the p22phox gene with diabetes mellitus type 2 and distal diabetic polyneuropathy. Mol Med Rep 2015;12:4626-33.

11. Simsek A, Aykut O. Evaluation of the microelement profile of turkish hazelnut (corylusavellana L.) varieties for human nutrition and health. Int J Food SciNutr. 2007;58(8):677-688.

12. Soetan KO, Olaiya CO, Oyewole OE. The importance of mineral elements for humans, domestic animals and plants: a review. Afr J Food Sci. 2010;4(5):220-222.

13. Grivetti L. Value of traditional foods in meeting of macro- and micronutrients needs: the wild plants connection. Nutr Res Rev. 2000;13:31-46.

14. Fraga CG. Relevance, essentiality and toxicity of trace elements in human health.Mol Aspects Med. 2005;26(45):235-244.

15. McCall KA, Huang C, Fierke CA. Function and mechanism of zinc metalloenzymes. J Nutr. 2000;130(5S Suppl):1437S-1446S.

16. Lu Y, Yeung N, Sieracki N, Marshall NM. Design of functional metalloproteins.Nature. 2009;460(7257):855862.

17. Lutsenko S, Barnes NL, Bartee MY, Dmitriev OY. Function and regulation of human copper-transporting ATPases.Physiol Rev. 2007;87(3):1011-1046.

18. Guidotti T, McNamara J, Moses M. The interpretation of trace element analysis in body fluids. Indian J Med Res. 2010;128(4):524.

19. Chen YW. Heavy metals, islet function and diabetes development. Islets. 2009;1(3):169-176. doi: 10.4161/isl.1.3.9262.

20. Valko M, Morris H, Cronin MT. Metals, toxicity and oxidative stress. Curr Med Chem. 2005;12(10):11611208. 